DOI: https://doi.org/10.24127/ajpm.v10i1.3265

\title{
ANALISIS KEMAMPUAN PEMAHAMAN KONSEP SISWA DALAM MENYELESAIKAN SOAL CERITA MATEMATIKA
}

\author{
Dian Mayasari ${ }^{1}$, Nova Lina Sari Habeahan², \\ ${ }^{1}$ Pendidikan Matematika, Universitas Musamus, Merauke, Indonesia \\ ${ }^{2}$ Pendidikan Bahasa dan Sastra Indonesia, Universitas Musamus, Merauke, Indonesia \\ *Corresponding author \\ E-mail: $\quad$ mayasarifkip@unmus.ac.id ${ }^{1)}$ \\ habeahan_fkip@unmus.ac.id ${ }^{2)}$
}

Received 24 November 2020; Received in revised form 04 March 2021; Accepted 06 April 2021

\begin{abstract}
Abstrak
Penelitian ini bertujuan untuk mendeskripsikan kemampuan pemahaman konsep siswa dalam menyelesaikan soal cerita. Subjek penelitian ialah 28 siswa kelas VII SMP Negeri 8 Merauke. Teknik pengumpulan data yang dilakukan berupa tes kemampuan siswa dalam memahami konsep dan wawancara yang tidak terstruktur. Tes yang digunakan untuk mengukur kemampuan pemahaman konsep berupa soal uraian sebanyak 4 soal dengan materi operasi bilangan bulat pada soal cerita. Sumber data penelitian ini adalah hasil tes dan hasil wawancara. Hasil penelitian ini menunjukkan bahwa pemahaman konsep matematis siswa dengan kategori tingi sebanyak 17\%, kategori sedang sebanyak $10 \%$, dan kategori rendah sebanyak $73 \%$. Hasil penelitian ini juga menunjukkan bahwa kinerja siswa dari masing-masing kategori adalah sebagai berikut: (a) siswa pada kategori tinggi dapat mengerjakan 4 butir soal atau menguasai 6 indikator kemampuan pemahaman konsep matematis; (b) siswa pada kategori sedang dapat mengerjakan 4 butir soal atau menguasai 6 indikator kemampuan pemahaman konsep matematis; dan (c) siswa pada kategori rendah dapat mengerjakan 4 butir soal atau menguasai 4 indikator kemampuan pemahaman konsep matematis. Melalui pemahaman konsep yang baik siswa dapat membantu siswa untuk meningkatkan kemampuan pemecahan masalah khususnya pada pelajaran matematika.
\end{abstract}

Kata kunci: Analisis; kemampuan; pemahaman konsep; soal cerita.

\begin{abstract}
This study aims to describe the ability of students to understand concepts in solving story problems. The research subjects were 28 grade VII students of SMP Negeri 8 Merauke. Data collection techniques were carried out in the form of tests of students' abilities in understanding concepts and unstructured interviews. The test used to measure the ability to understand the concept is in the form of description questions as many as 4 questions with integer operation material on the story problem. The data sources of this research are test results and interview results. The results of this study indicate that students' understanding of mathematical concepts with high category is $17 \%$, medium category is $10 \%$, and low category is $73 \%$. The results of this study also indicate that the performance of students from each category is as follows: (a) students in the high category can work on 4 items or master 6 indicators of the ability to understand mathematical concepts; (b) students in the moderate category can work on 4 items or master 6 indicators of the ability to understand mathematical concepts; and (c) students in the low category can work on 4 items or master 4 indicators of the ability to understand mathematical concepts. Through a good understanding of concepts students can help students to improve problem solving skills, especially in mathematics lessons.
\end{abstract}

Keywords: Ability; analysis; mathematical understanding; word problem.

This is an open access article under the Creative Commons Attribution 4.0 International License 
DOI: https://doi.org/10.24127/ajpm.v10i1.3265

\section{PENDAHULUAN}

Memahami konsep materi merupakan dasar bagi seseorang untuk menyelesaikan masalah (NCTM, 2000). Tujuan belajar mengajar matematika di sekolah menengah ialah untuk memahami konsep matematika, mendeskripsikan hubungan antara konsep dan menerapkan konsep atau algoritma dalam menyelesaikan masalah secara fleksibel (MoE, 2015). Kemampuan seseorang yang berhubungan dengan paham ide matematika secara menyeluruh dan fungsional disebut pemahaman konsep (Kilpatrick, Jane, \& Findell, 2005). Faktanya hasil Trend In International Mathematics And Science Study (TIMSS) tahun 2015, Indonesia berada pada rangking ke-44 dari 49 negara dengan nilai rerata skor Indonesia 397 dan rerata skor internasional 500 (Hadi \& Novaliyosi, 2019; Minarni, Napitupulu, \& Husein, 2016).

Pencapaian Indonesia berdasarkan kemampuan dimana kemampuan rendah sebanyak 54\%, kemampuan sedang $15 \%$ dan kemampuan tinggi sebanyak 6\%. Dari data diatas mengindikasikan bahwa kemampuan siswa Indonesia dalam menyelesaikan soal termasuk kategori rendah dengan rerata nilai 397.

Dari data tersebut pencapaian Indonesia tergolong rendah, hal ini dikarenakan kurangnya pemahaman konsep siswa terhadap matematika. Siswa cenderung menjadikan guru sebagai satu satunya sumber informasi dan masalah yang diberikan guru kepada siswa cenderung bersifat soal rutin. Senada dengan hal tersebut melalui wawancara denga guru matematika bahwa kemampuan siswa daalam pelajaran matematika rendah serta data nilai UN tahun 2017 mata pelajaran matematika di SMP Negeri 8 Merauke mendapatkan rerata 31,80.
Penelitian ini mengindikasikan bahwa kemampuan matematika siswa rendah dikarenakan pembelajaran berpusat pada guru serta siswa jarang dilibatkan dalam menyelesaikan masalah matematika.

Hasil penelitian dari Melinda (2019) menyimpulkan bahwa kendala dalam pelajaran matematika ialah perhitungan yang sederhana menghubungkan antara konsep yang satu dengan yang lain, rumus yang digunakan untuk menyelesaikan masih tertukar. Pangadongan (2015) dalam penelitiannya menyimpulkan bahwa faktor yang mempengaruhi siswa dalam

Hasil penelitian Wahyuddin (2017) Pagiling (2019) kendala menyelesaikan soal cerita siswa ialah 1) pemahaman menuliskan yang diketahui serta ditanyakan dalam soal, 2) pemahaman menuliskan model matematika, 3) kemampuan menyelesaikan masalah.

Permasalahannya ialah bagaimana cara untuk mendeskripsikan kemampuan pemahaman konsep siswa dalam menyelesaikan soal cerita. Dimana indikator pemahaman konsep Peraturan pemerintah pendidikan dasar dan menengah No 506/C/KepPP/2004 menyatakan bahwa siswa mampu memahami konsep apabila 1) menggunakan gambar untuk membantu menyelesaikan masalah, 2) memberikan contoh dan bukan contoh untuk sebuah konsep, 3) mengklasifikasikan contoh ke dalam sebuah konsep, 4) mampu menerapkan persamaan matematika antara konsep dan prosedur, 5) memahami dan menggunakan pola yang tepat untuk memecahkan masalah, 6) menerapkan persamaan atau perbedaan untuk menyelesaikan masalah, 7) jelaskan solusinya.

Kemampuan di atas akan berguna bagi siswa dalam menyelesaikan 
masalah yang berhubungan dengan keseharian mereka. Perkembangan pelajaran matematika saat ini lebih menakankan pada penerapan konsep yang menghubungkan antara kehidupan sehari-hari siswa dengan matematika (Pangadongan, 2015). Materi pelajaran yang diterapkan diharapkan dapat menerapkan situasi nyata dengan tujuan siswa dapat mengaitkan masalah seharihari dengan matematika sehingga kemampuan pemahaman siswa dapat meningkat (Aminah \& Ayu Kurniawati, 2018; Sulestry \& Meliyana, 2016). Penerapan kemampuan pemahaman konsep siswa dapat dilakukan dalam soal cerita. Melalui pengaplikasian masalah keseharian dengan pertanyaan cerita yang berhubungan dengan matematika. Hal itu akan membuat siswa lebih paham mengenai materi ajar (Agustina, Syaifudin, \& Supriadi, 2019).

Pada kenyataanya pembelajaran yang terjadi di lapangan masih menggunakan soal-soal yang bersifat konteks. Dimana setelah guru selesai menyajikan materi pembelajaran, guru memberikan soal langsung kepada siswa tanpa menghubungkan kehidupan sehari-hari dengan matematika. Dalam menyelesaikan soal, siswa terburu-buru mencatat setiap konsep dari materi yang disampaikan tanpa mengerti dengan apa yang dicatatnya. Bahkan siswa kurang mampu memahami konsep yang ada pada catatannya kembali ketika diberikan soal latihan. Jika ini terus dibiarkan maka siswa akan terlatih menjadi siswa yang manja dan berdampak negatif terhadap hasil belajarnya.

Dengan demikian melalui pamahaman konsep dapat membantu siswa untuk mengerti apa yang dimaksud, mampu menemukan cara untuk menyatakan konsep tersebut, serta mampu unutk mengeksplorasi kemungkinan terkait penyelesailan mmasalah (Hakim \& Ramlah, 2019). Berdasarkan latar belakang, masalah pada penelitian ini untuk melihat bagaimana kemampuan pemahaman konsep siswa dalam menyelesaikan soal cerita.

\section{METODE PENELITIAN}

Penelitian ini termasuk jenis deskriptif dengan pendekatan kualitatif. Penelitian ini bertujuan untuk mendeskripsikan kemampuan pemahaman konsep siswa dalam menyelesaikan soal cerita. Materi yang diterapkan dalam penelitian ini ialah sampai pada bilangan bulat. Subjek penelitian ialah siswa SMP Negeri 8 Merauke kelas VII. Dengan jumlah siswa 28 terdiri dari 16 laki-laki dan 12 Perempuan. Siswa yang menjadi subjek penelitian terdiri dari 9 orang yang dibagi berdasarkan kemampuan mereka. Dimana siswa yang berkemampuan tinggi sebanyak 3 orang, 3 orang siswa berkemampuan sedang dan 3 orang siswa berkemampuan rendah.

Instrumen yang digunakan dalam penelitian ini ialah tes kemampuan pemahaman konsep dan pedoman wawancara. Tes kemampuan pemahaman konsep mengacu pada indikator pemahaman konsep ialah 1) menggunakan gambar untuk membantu menyelesaikan masalah, 2) memberikan contoh dan bukan contoh untuk sebuah konsep, 3) mengklasifikasikan contoh ke dalam sebuah konsep, 4) mampu menerapkan persamaan matematika antara konsep dan prosedur, 5) memahami dan menggunakan pola yang tepat untuk memecahkan masalah, 6) menerapkan persamaan atau perbedaan untuk menyelesaikan masalah, 7) jelaskan solusinya. Sedangkan wawancara yang digunakan dalam 
penelitian ini ialah untuk mendapatkan informasi secara detail mengenai indikator pemahaman konsep dan menghubungkan dengan hasil penyelesaian siswa dalam memecahkan masalah yang bebentuk cerita tersebut.

Analisis data yang digunakan adalah dengan reduksi data melalui kegiatan penyerdehanaan kegiatan tes, wawancara dan dokumentasi. Selanjutnya dilakukan penyajian data dilakukan dengan menyusun sekumpulan informasi dari hasil reduksi data. Data yang telah disusun kemudian diinterpretasikan untuk mengevaluasi data yang telah disajikan. Untuk mengukur presentasi keterpenuhan dari tiap indikator pemahaman konsep ialah:

$$
P_{i}=\frac{Q_{i}}{r} x 100 \%
$$

Keterangan:

$P_{i}=$ persentasi kesesuaian indikator $Q_{i}=$ besarnya subjek yang mencukupi indikator pemahaman konsep

$r=$ besarnya subjek uji coba

\section{HASIL DAN PEMBAHASAN}

Jumlah siswa kelas VIII A adalah 28 orang. Pada awal kegiatan telah dilakukan tes untuk data awal. Pengambilan data awal bertujuan untuk mengetahui kemampuan awal pemahaman konsep matematis yang dimiliki oleh siswa setelah pembelajaran sistem persamaan linear dua variabel. Setelah diperoleh hasil, siswa dikelompokkan menjadi tiga kategori sesuai dengan kemampuan matematika siswa. Ketiga kategori tersebut adalah tinggi $(\mathrm{T})$, sedang $(\mathrm{S})$, dan rendah $(\mathrm{R})$. Hasil dari tes kemampuan awal siswa dapat dilihat pada Gambar 1.

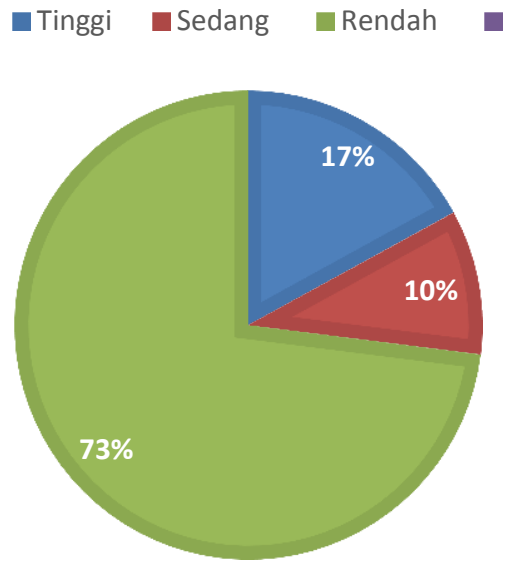

Gambar 1. Persentase pemahaman konsep matematis siswa

Jika dilihat dari Gambar 1, diperlihatkan bahwa $73 \%$ atau 22 orang siswa termasuk kategori rendah dalam memahami konsep dan hanya $17 \%$ atau 4 orang siswa yang termasuk kategori tinggi dalam memahami konsep. Hal ini dikarenakan siswa telah terbiasa menyelesaikan soal yang sama seperti yang dijelaskan oleh guru, atau siswa hanya terbiasa untuk menyelesaikan maslah yang sifatnya rutin.

Setelah dikelompokkan berdasarkan kategori tinggi, sedang, dan rendah kemudian dipilih subjek penelitian untuk masing-masing kategori dengan kriteria yang telah ditentukan sebelumnya dan terpilih subjek S2 untuk kategori kemampuan matematika tinggi, S7 untuk kategori kemampuan matematika sedang, dan S13 untuk kategori kemampuan matematika rendah.

Pembahasan untuk hasil jawaban siswa didasarkan pada indikator pemahaman konsep. Akan tetapi, sebelum membahas hasil dari jawaban siswa, perlu diketahui soal-soal tes yang digunakan pada penelitian ini seperti dapat dilihat pada Tabel 1 . 
DOI: https://doi.org/10.24127/ajpm.v10i1.3265

Tabel 1. Soal-soal tes

\begin{tabular}{cl}
\hline No & \multicolumn{1}{c}{ Soal } \\
\hline 1 & Terjadi peristiwa banjir di daerah Merauke, seorang aktivis bernama Pak Didin \\
& membantu korban banjir selama 15 hari. 2 dus mie instan dibagi terhadap tiap \\
& kepala keluarga, terdapat 120 keluarga yang menjadi korban banjir. Berapa \\
& jumlah dus mi instan yang telah dibagikan pak Didin? \\
2 & Alfin mendapat uang saku dari Ibu Rp35.000 per minggu. Sekolah Alfin sudah \\
& menerapkan sistem Full Day sehingga hari Sabtu dan Minggu libur. Karena hari \\
& libur Alfin berada dirumah maka ia tidak jajan. Uang yang tidak dijajankan ia \\
& tabungkan untuk membeli mainan robot. Mainan itu dapat dibeli apabila ia \\
& menabung selama 6 minggu. Berapakah harga mainan robot tersebut? \\
3 & Ivan ingin membeli sebuah mainan tetapi uangnya belum cukup. Mulai esok \\
& harinya Ivan menabung sebanyak Rp.5.000,00 tiap hari, setelah 25 hari uang \\
& Ivan menjadi Rp225.000,00. Berapakah uang Ivan mula-mula? \\
& Buatlah contoh operasi bilangan bukan dalam bentuk garis bilangan!
\end{tabular}

Selanjutnya adalah deskripsi dari hasil jawaban siswa terhadap masing-masing soal. Soal nomor 1 memuat indikator menyatakan ulang sebuah konsep, menerapkan persamaan atau perbedaan untuk menyelesaikan masalah dan menjelaskan solusi. Hasil dan deskripsi dari peyelesaian pada soal nomor 1 dapat dilihat pada Tabel 2.

Tabel 2. Deskripsi penyelesaian siswa untuk soal nomor 1

\begin{tabular}{clc}
\hline No & \multicolumn{1}{c}{ Deskripsi Penyelesaian Siswa } & $\begin{array}{c}\text { Banyak } \\
\text { Siswa }\end{array}$ \\
\hline 1 & $\begin{array}{l}\text { Menggunakan konsep atau prosedur penyelesaian yang salah } \\
2\end{array}$ & 20 \\
& $\begin{array}{l}\text { Menunjukkan aspek pemahaman matematis yang sesuai dengan } \\
\text { masalah tetapi penyelesaian akhir yang salah }\end{array}$ & 4 \\
3 & $\begin{array}{l}\text { Menunjukkan aspek pemahaman matematis yang sesuai dengan } \\
\text { masalah dan operasi lengkap tapi mengarah ke jawaban yang salah }\end{array}$ & 1 \\
4 & $\begin{array}{l}\text { Menunjukkan aspek pemahaman matematis yang sesuai dengan } \\
\text { masalah dan operasi lengkap tapi mengarah ke jawaban yang benar }\end{array}$ & 2 \\
\hline
\end{tabular}

Berdasarkan Tabel 2, dalam menyelesaikan soal nomor 1 terdapat 20 siswa yang salah menggunakan konsep atau prosedur penyelesaian dimana siswa belum memahami konsep dengan baik. Terdapat 4 siswa yang dapat menunjukkan aspek pemahaman matematis yang sesuai tetapi penyelesaiannya salah dalam hal ini siswa telah memahami konsep dalam menyelesaikan masalah tetapi tidak dapat menyelesaikannya. Terdapat 1 orang siswa yang memahami konsep dan menyelesaikan sesuai dengan konsep tapi mengarah pada hasil yang salah berarti siswa dalam hal ini siswa telah paham menggunakan konsep tapi pada akhir penyelesaian salah. Terdapat 2 siswa yang memahami konsep, menyelesaikan masalah sesuai dengan jawaban benar berarti hanya 2 orang yang memiliki kemampuan pemahaman konsep dengan baik.

Selanjutnya adalah pembahasan untuk soal nomor 2 yang memuat indikator memahami dan menggunakan pola yang tepat untuk memecahkan masalah, menerapkan persamaan atau 
DOI: https://doi.org/10.24127/ajpm.v10i1.3265

perbedaan untuk menyelesaikan masalah. Hasil deskripsi siswa dalam

menyelesaikan soal nomor 2 dapat dilihat pada Tabel 3 .

Tabel 3. Deskripsi penyelesaian siswa untuk soal nomor 2 .

\begin{tabular}{clc}
\hline No & \multicolumn{1}{c}{ Deskripsi Penyelesaian Siswa } & $\begin{array}{c}\text { Banyak } \\
\text { Siswa }\end{array}$ \\
\hline 1 & $\begin{array}{l}\text { Menggunakan konsep atau prosedur penyelesaian yang salah } \\
2\end{array}$ & $\begin{array}{l}\text { Menunjukkan aspek pemahaman matematis yang sesuai dengan } \\
\text { masalah tetapi penyelesaian akhir yang salah }\end{array}$ \\
3 & $\begin{array}{l}\text { Menunjukkan aspek pemahaman matematis yang sesuai dengan } \\
\text { masalah dan operasi lengkap tapi mengarah ke jawaban yang salah }\end{array}$ & 2 \\
\hline 4 & $\begin{array}{l}\text { Menunjukkan aspek pemahaman matematis yang sesuai dengan } \\
\text { masalah dan operasi lengkap tapi mengarah ke jawaban yang benar }\end{array}$ & 3 \\
\hline
\end{tabular}

Berdasarkan Tabel 3, dalam menyelesaikan soal nomor 2 terdapat 20 siswa yang salah dalam menggunakan konsep dalam menyelesaikan masalah. terdapat 2 siswa yang dapat menunjukkan pemahaman matematis yag sesuai tetapi penyelesaian akhir yang salah. Terdapat 3 orang sisswa yang dapat menunjukkan aspek pemahaman konsep serta operasi lengkap tetapi menghasilkan penyelesaian yang salah. Terdapat 3 orang siswa yang dapat menggunakankonsep yangs esuai dan mengarah pada jawaban yang benar.

Pembahasan selanjutnya adalah pembahasan untuk hasil dan jawaban soal nomor 3. Soal nomo3 memuat indikator mengklasifikasikan contoh ke dalam sebuah konsep dan mampu menerapkan persamaan matematika antara konsep dan prosedur. Hasil deskripsi siswa dalam menyelesaikan soal nomor 3 dapat dilihat pada Tabel 4.

Tabel 4. Deskripsi penyelesaian siswa untuk soal nomor 3 .

\begin{tabular}{clc}
\hline No & \multicolumn{1}{c}{ Deskripsi Penyelesaian Siswa } & Banyak Siswa \\
\hline 1 & $\begin{array}{l}\text { Menggunakan konsep atau prosedur penyelesaian yang salah } \\
2\end{array}$ & $\begin{array}{l}\text { Menunjukkan aspek pemahaman matematis yang sesuai dengan } \\
\text { masalah tetapi penyelesaian akhir yang salah }\end{array}$ \\
3 & $\begin{array}{l}\text { Menunjukkan aspek pemahaman matematis yang sesuai dengan } \\
\text { masalah dan operasi lengkap tapi mengarah ke jawaban yang } \\
\text { salah }\end{array}$ & 8 \\
& $\begin{array}{l}\text { Menunjukkan aspek pemahaman matematis yang sesuai dengan } \\
\text { masalah dan operasi lengkap tapi mengarah ke jawaban yang } \\
\text { benar }\end{array}$ & 5 \\
\hline
\end{tabular}

Berdasarkan Tabel 4, terdapat 13 orang siswa yang salah dalam menggunakan konsep untuk menyelesiakan soal. Terdapat 1 orang siswa yang dapat menggunakan konsep yang sesuai tetapi mengarah pada jawaban yang salah . Terdapat 8 orang siswa yang memahami konsep dengan baik. Terdapat 5 siswa yang dapat memahami konsep dengan baik dan mengarah pada jawaban yang benar.

Pembahasan terakhir, yaitu pembahasan soal nomor 4 yang memuat indikator menggunakan gambar utuk membantu memecahkan masalah, dan memberikan contoh dan bukan contoh 
DOI: https://doi.org/10.24127/ajpm.v10i1.3265

untuk sebuah konsep. Hasil dan dilihat pada Tabel 5 . deskripsi dari jawaban siswa dapat

Tabel 5. Deskripsi penyelesaian siswa soal nomor 4 .

\begin{tabular}{clc}
\hline No & \multicolumn{1}{c}{ Deskripsi Penyelesaian Siswa } & Banyak Siswa \\
\hline 1 & Menggunakan konsep atau prosedur penyelesaian yang salah & 10 \\
\hline 2 & $\begin{array}{l}\text { Menunjukkan aspek pemahaman matematis yang sesuai } \\
\text { dengan masalah tetapi penyelesaian akhir yang salah }\end{array}$ & 6 \\
3 & $\begin{array}{l}\text { Menunjukkan aspek pemahaman matematis yang sesuai } \\
\text { dengan masalah dan operasi lengkap tapi mengarah ke } \\
\text { jawaban yang salah }\end{array}$ & 2 \\
$\begin{array}{l}\text { Menunjukkan aspek pemahaman matematis yang sesuai } \\
\text { dengan masalah dan operasi lengkap tapi mengarah ke } \\
\text { jawaban yang benar }\end{array}$ & 8 \\
\hline
\end{tabular}

Berdasarkan Tabel 5, terdapat 10 orang siswa yang salah dalam menggnakan konsep serta prosedur penyelesaian. Terdapat 6 orang siswa yang memahamin konsep dalam menyelesiakan tetapi mengarapada hasil yangsalah. Terdapat 2 orang siswa yang paham konsep dan operasi lengkap tetapi mengarah pada jawaban yang salah. Terdapat 8 orang siswa yang memahami masalah masalah serta menggunakan konsep yang benar dan mengarah pada jawaban yang benar.

Dari wawancara pada siswa S2 menunjukkan bahwa siswa belum memahami secara benar tentang konsep operasi bilangan bulat, S2 tidak dapat menyatakan ulang konsep serta penerapannya dalam menyelesaikan masalah. Akhirnya saat wawancara, peneliti memberi bimbingan berupa pertanyaan tentang konsep operasi bilangan bulat. Pada penyelesaian soal, siswa S2 dapat memberikan contoh operasi bilangan bulat, saat S2 seperti tidak yakin dalam menuliskan konsep yang sesuai utnuk menyelesaikan soal peneliti mengarahkan siswa untuk memilih konsep yang tepat. Dengan demikian pemahaman konsep dengan indikator menyatakan ulang sebuah konsep, menerapkan persamaan atau perbedaan untuk menyelesaikan masalah dan menjelaskan solusi siswa S2 sudah baik.

Siswa S7 dapat menggambar dan memberikan contoh dan bukan contoh sesuai konsep dengan baik. S7 dapat mengklasifikasikan persamaan matematika tetapi kurang dalam penerapannya pada soal. Siswa S7 hanya dapat menuliskan konsep tidak dapat memberikan pengertian atau penjelesan berdasarkan yang S7 telah pelajari. Ini menunjukkan S7 pada indikator menggunakan konsep yang sesuai dalam menyelesaikan masalah masih rendah. Melalui hasil wawancara, siswa S7 memahami pola yang tepat untuk menyelesaikan soal tetapi siswa bingung dalam menerapkan pola tersebut dalam menyelesaikan masalah. Tapi ketika siswa S7 diberikan soal untuk diselesakan, dia mampu menentukan pola yang sesuai tapi perlu arahan untuk menerapkan pola tersebut.

Dalam menyelesaikan soal, siswa S13 tidak dapat memberikan contoh dari operasi bilangan bulat. Saat ditanya, S13 kebanyakan lupa saat ditanya. Ketika peneliti memberikan soal secara langsung dengan siswa S13 dia terlihat tidak yakin dalam menyelesaikannya. Hal ini disebabkan 
karena siswa S13 tidak memahami konsep operasi bilangan bulat, sehingga dalam menyelesaikan soal siswa S13 tidak menyelesaikan soal tersebut.

Berdasarkan hasil analisis wawancara diperoleh gambaran kemampuan pemahaman konsep matematis siswa kategori tinggi, kategori sedang dan kategori rendah dalam menyelesaikan masalah yaitu:

1. Kemampuan pemahaman konsep matematis kategori tinggi S2

Hal yang cukup sulit bagi S2 ketika menyatakan ulang sebuah konsep, dimana S2 tidak dapat menjelaskan pengertian dari operasi bilangan bulat dengan bahasanya sendiri. Saat menjawab soal juga ada beberapa kesalahan pada operasi bilangan bulat yang dilakukan siswa. Secara keseluruhan, dalam menyelesaikan masalah operasi bilangan bulat, S2 dapat menunjukkan kemampuan pemahaman konsep matematis.

2. Kemampuan pemahaman konsep matematis kategori sedang S7. Hal yang cukup sulit bagi S7 ketika menyatakan ulang sebuah konsep, dimana S7 juga tidak dapat menjelaskan pengertian dari operasi bilangan bulat dengan bahasanya sendiri. Kesalahankesalahan yang juga dilakukan S7 adalah saat mengoperasikan bilangan bulat.Secara keseluruhan, dalam menyelesaikan masalah operasi bilangan bulat, S7 dapat menunjukkan kemampuan pemahaman konsep matematis dan memilih prosedur tertentu, mengaplikasikan konsep pemecahan masalah.

3. Kemampuan pemahaman konsep matematis kategori rendah S13

Hal yang cukup sulit bagi S13 ketika menyatakan ulang sebuah konsep, dimana S13 tidak dapat menjelaskan pengertian dari operasi bilangan bulat dengan bahasanya sendiri, sehingga pada nomor 2 dengan indikator memberikan contoh dan bukan contoh S13 juga tidak dapat menjawab soal tersebut. S13 juga mengalami kesulitan saat membuat beberapa model matematika yaitu pada soal nomor 6 dan 7, sehingga butuh bantuan peneliti dalam membuat beberapa persamaan tersebut. Secara keseluruhan, dalam menyelesaikan masalah sistem persamaan linear, S13 dapat menunjukkan kemampuan pemahaman konsep matematis.

Hasil penelitian ini sejalan dengan penelitian yang dilakukan oleh Fajar, Kodirun, Suhar, \& Arapu (2019) bahwa terdapat $87 \%$ siswa memiliki kemampuan pemahaman konsep rendah. Hal ini disebabkan karena dalam pembelajaran siswa terburu-buru mencatat konsep yang diberikan guru tanpa memahami apa yang telah ditulisnya serta siswa dalam menyelesaikan soal membahasi soal yang rutin dan sesuai dengan contoh yang diberikan guru (Pande, Ayu, Astawa, \& Mahayukti, 2019). Berdasarkan peneltian ini kemampuan pemahamankosnep siswa rendah disebabkan oleh ketidakmampuan siswa dalam memahami konsep serta menggunakan konsep yang sesuai dengan masalah. Dengan demikian untuk meningkatkan kemmapuan pemahaman konsep siswa perlu adanya pemberian masalah non rutin dan disesuaikan dengan indikator pemahaman konsep. Selain itu dalam proses pembelajaran guru perlu menghubungkan pengalaman keseharian siswa untuk memudahkan pemahaman materi pembelajaran.

Hal ini sejalan dengan kajian kesulitan siswa dalam menyelesaikan 
soal cerita bahwa guru dalam pembelajaran menggunakan model pembelajaran yang disesuaikan dengan kondisi siswa (Azis, 2019). Penelitian ini memperlihatkan bahwa dalam kesehariannya siswa terbiasa menyelesaikan soal dan proses penyelesaian yang mirip dengan yang diberikan oleh guru sehingga dalam menyelesaikan soal non rutin tidak dapat memberikan jawaban yang bernar sesuai dengan indikator pemahaman konsep.

Penelitian ini mempunyai pengaruh terhadap pendidikan khususnya pelajaran matematika karena untuk meningkatkan hasil belajar perlu adanya pelaksanaan kegiatan belajar menggunakan model pembelajaran yang sesuai dengan kondisi siswa serta menggunakan masalah non rutin dalam membuat serta menyelesaikan masalah.

\section{KESIMPULAN DAN SARAN}

Berdasarkan dari hasil analisis data dan pembahasan, maka dapat disimpulkan bahwa kemampuan pemahaman konsep siswa masih rendah. Hal ini dilihat melalui hasil tes kemampuan pemahaman konsep. Hasil penelitian ini akan dijadikan informasi kepada guru mengetahui pemahaman konsep yang dimiliki siswa pada pelajaran matematika. Kemampuan pemahaman konsep penting dalam pembelajaran matematika sehingga guru diharapkan mampu merancang kegiatan belajar untuk meningkatkan kemampuan pemahaman konsep. Dalam hal ini disarankan untuk penelitian selanjutnya 1)melakukan penelitian untuk melihat kemampuan pemahaman konsep matematika pada materi ajar yang lain. 2) mengembangkan/ merancang pembelajaran untuk meningkatkan kemampuan pemahaman konsep siswa.

\section{UCAPAN TERIMA KASIH}

Terima kasih kepada Universitas Musamus khususnya LPPM Nomor DIPA : 315/UN52/KP/2020 tanggal 29 Juli 2020 yang telah mendanai penelitian ini dengan kontrak penelitian dosen pemula Tahun Anggaran 2020

\section{DAFTAR PUSTAKA}

Agustina, Syaifudin, \& Supriadi, A. (2019). Analisis Kemampuan Pemahaman Siswa Dalam Menyelesaikan Soal Cerita Program Linear Di Kelas XI. GAUSS: Jurnal Pendidikan Matematika, 02(01), 1-12.

Aminah, A., \& Ayu Kurniawati, K. R. (2018). Analisis Kesulitan Siswa Dalam Menyelesaikan Soal Cerita Matematika Topik Pecahan Ditinjau Dari Gender. JTAM | Jurnal Teori Dan Aplikasi Matematika, 2(2), 118. https://doi.org/10.31764/jtam.v2i2. 713

Azis. (2019). Analisis Kesulitan Siswa Dalam Menyelesaikan Soal Cerita Pada Pembelajaran Matematika Kelas VIII. Media Pendidikan Matematika, $7(1), \quad 72$. https://doi.org/10.33394/mpm.v7i1 .1679

Fajar, A. P., Kodirun, K., Suhar, S., \& Arapu, L. (2019). Analisis Kemampuan Pemahaman Konsep Matematis Siswa Kelas VIII SMP Negeri 17 Kendari. Jurnal Pendidikan Matematika, 9(2), 229. https://doi.org/10.36709/jpm.v9i2. 5872

Hadi, S., \& Novaliyosi. (2019). TIMSS Indonesia (Trends in International Mathematics and Science Study ). Prosiding Seminar Nasional Universitas Siliwangi, 562-569. Tasikmalaya: Program Studi Magister Pendidikan Matematika 
Universitas Siliwangi.

Hakim, I. D., \& Ramlah. (2019). Analisis Kemampuan Pemahaman Konsep Materi Segitiga dan Segiempat pada Siswa SMP. Prosiding Seminar Nasional Matematika Dan Pendidikan Matematika Sesiomadika, (22), 1015-1026.

Kilpatrick, J., Jane, S., \& Findell, B. (2005). Adding It Up: Helping Children Learn Mathematics. In N. R. C. Mathematics Learning Study Committee (Ed.), Social Sciences. Washington,DC: National Academy Press.

Minarni, A., Napitupulu, E. E., \& Husein, R. (2016). Mathematical understanding and representation ability of public junior high school in North Sumatra. Journal on Mathematics Education, 7(1), 4356.

https://doi.org/10.22342/jme.7.1.28 16.43-56

MoE. (2015). The Management of National Education In 2014/2015 At a Glance (Sudarwati, ed.). Jakarta: Center for Educational and Cultural Data and Statistics, MoEC, 2016.

NCTM. (2000). Principles and Standars for School Mathematics (The National Ciuncil of Teacher of Mathematics, ed.). United State of America.

Pagiling, S., Palobo, M., Munfarikhatin, A., Mayasari, D., \& Taufik, A. (2019). Exploration of College Student's Representations in Solve The Problem of Numeric Methods. 363(Icss), 134-136. https://doi.org/10.2991/icss19.2019.212

Pande, N., Ayu, K., Astawa, I. W. P., \& Mahayukti, G. A. (2019). Missouri Mathematics Project ( MMP ),
Pemahaman Konsep Matematika , dan Kepercayaan Diri Siswa. Jurnal Elemen, 5(2), 178-189. https://doi.org/10.29408/jel.v5i2.13 17

Pangadongan, F. V. (2015). Konsepsi Siswa SMP Pada Materi Segiempat Ditinjau dari Gaya Belajar. Seminar Nasinal Matematika Dan Pendidikan Matematika UNY, 1001-1008.

Rismawati, M., \& Asnayani, M. (2019). Analisis Kesalahan Konsep Siswa Kelas Iv Dalam Menyelesaikan Soal Ulangan Matematika Dengan Metode Newman. J-PiMat : Jurnal Pendidikan Matematika, 1(2), 6978. https://doi.org/10.31932/jpimat.v1i2.495

Sulestry, A. I., \& Meliyana, S. M. (2016). Analisis Kemampuan Menyelesaikan Soal Cerita Matematika Siswa Kelas Viii Smp Negeri 1 Bulukumba. Prosiding Seminar Nasional, 03(1), 212-220. https://doi.org/10.1042/BST03903 78

Wahyuddin, W. (2017). Analisis Kemampuan Menyelesaikan Soal Cerita Matematika Ditinjau dari Kemampuan Verbal. Beta Jurnal Tadris Matematika, 9(2), 148. https://doi.org/10.20414/betajtm.v9 i2.9 